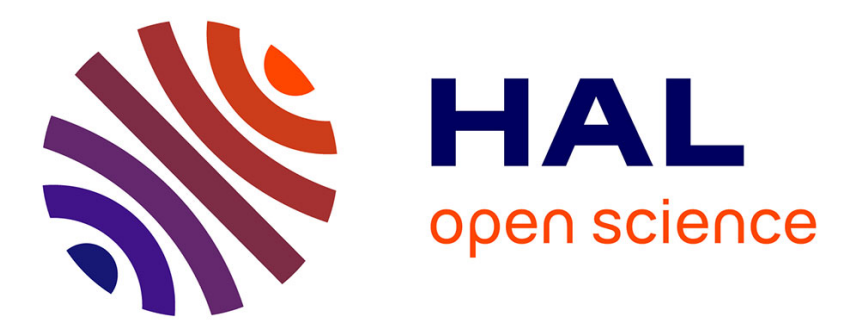

\title{
Review symposium: What went wrong with liberal multiculturalism? \\ Rainer Bauböck
}

\section{To cite this version:}

Rainer Bauböck. Review symposium: What went wrong with liberal multiculturalism?. Ethnicities, 2008, 8 (2), pp.271-276. 10.1177/14687968080080020105 . hal-00571898

\section{HAL Id: hal-00571898 \\ https://hal.science/hal-00571898}

Submitted on 1 Mar 2011

HAL is a multi-disciplinary open access archive for the deposit and dissemination of scientific research documents, whether they are published or not. The documents may come from teaching and research institutions in France or abroad, or from public or private research centers.
L'archive ouverte pluridisciplinaire HAL, est destinée au dépôt et à la diffusion de documents scientifiques de niveau recherche, publiés ou non, émanant des établissements d'enseignement et de recherche français ou étrangers, des laboratoires publics ou privés. 


\section{What went wrong with liberal multiculturalism?}

\section{RAINER BAUBÖCK}

European University Institute, Italy

In contrast with other contributions to this review symposium, I share Will Kymlicka's assessment of the virtues of liberal multiculturalism and his desire to further elaborate its repertoire so that it may become acceptable and applicable under conditions that are radically different from, and much less favourable than, those prevailing in western democracies.

In his new book, Kymlicka suggests that, after strongly promoting liberal multiculturalism in the 1990s, international law and international organizations are now caught in an impasse and likely to retreat. I am not sure that this diagnosis is correct. Multiculturalism is certainly under attack in Europe, but may still be alive and kicking under different names in other parts of the world. The adoption of the UN Declaration on the Rights of Indigenous Peoples shortly after publication of Kymlicka's book - albeit in a watered-down version - suggests at least that progress on some fronts is still possible. However, there is certainly a strong sense of doubt about the task description, and chances of success for international efforts to promote liberal solutions to multicultural conflicts seem to have become dimmer.

I see three possible diagnoses for the current malaise. The first one is that this is as good as it gets. The international communities' commitment to multiculturalism may have been genuine, insofar as it has been perceived as a natural extension of the human rights agenda and as a means to defuse dangerous ethno-national conflicts, but it has now reached its limits. After all, international organizations operate within the normative framework of the Westphalian state system and are committed to maintaining this framework. Where liberal multiculturalism is seen to conflict with its normative foundations, it has to give way.

The second diagnosis is that we are witnessing a real backlash. Maybe the international community's commitment was not genuine but merely conditional. Multiculturalism was supported insofar as it was seen to contribute to the more fundamental goals of peace, democracy and development. Now there are doubts, nourished by an increasing number of public intellectuals, not only about exporting multicultural solutions to post-communist and developing countries, but also about their effects on social solidarity, gender equality and overall societal cohesion in western democracies.

A third diagnosis focuses instead on the justification of liberal multiculturalism. It responds to the second one that there may be less wrong with 
the actual policies of multiculturalism than with some of their ideological underpinnings. It would certainly be naive to suggest that the lack of good theories is a major cause of political retreat. Real-world obstacles are well identified in Kymlicka's book, and my first and second diagnoses are probably both part of a fuller explanation. But in order to build a case against retreat, it may not be enough to take into account non-western contexts, to add more specific instruments that target different types of claims, and to adopt a strategy of sequencing cultural rights, as Kymlicka suggests in the concluding chapter of his book. We also need a more coherent defence of multiculturalism that resonates with the most progressive aspects of international law. This is anyway all that academics committed to liberal multiculturalism can do.

The problem I see with Kymlicka's defence of liberal multiculturalism is that it remains too strongly rooted in a culturalist version of liberal nationalism. Liberal nationalism shares with all other kinds of nationalism the view that, ideally, political and cultural boundaries should coincide. What makes liberal nationalism liberal are two further ideas. First, belonging to a national community is not an intrinsic value, but an instrumental one. ${ }^{1}$ It is important for individual autonomy and well-being (Tamir, 1993, Kymlicka, 1995) or for social justice and solidarity among citizens (Miller, 1995). Second, since all individuals have equal rights to autonomy and well-being or to citizenship in a democratic state, the communities to which they are affiliated must also be treated equally. It follows that every nation has the same claim to self-determination and that minorities have rights to protect their culture against dominant majorities through pursuing their own projects of nation building.

This theoretical framework cannot be fully shared by international organizations and lawyers. An equal right to self-determination for all nations would immediately conflict with the basic Westphalian norm of territorial integrity of states. International law does, however, support a principle of 'self-determination of peoples'. In order to reconcile this with the territorial integrity of states, 'peoples' have been defined more narrowly than 'nations' (Cassese, 1995).

Unlike normative theorists, international lawyers do not have to build coherent theories, but interpret norms they find in treaties and evolving state practices. The break-up of the Soviet Union and Yugoslavia has led to new interpretations of self-determination, but there is still wide agreement that it does not entail a right of stateless nations to secession and independence. Theories of multiculturalism that appear to endorse such rights will be looked at suspiciously by most international organizations and lawyers. This may explain their reluctance to go any further that I associate with the first diagnosis above.

Kymlicka is not very explicit on this point. He is aware that international organizations have strong security concerns about threats to territorial 
integrity, but it is less clear whether he thinks that liberal justice requires a right of nations to self-determination. In his view, national majorities have to grant demands for minority self-government as a matter of justice, but he does not seem to support analogous obligations of minorities who have been granted strong autonomy to respect the territorial integrity of multinational democracies (see Kymlicka, 2001: Ch. 5). Ambiguity on this point may, however, be fatal for a theory that aims to inform a morally coherent and politically sustainable approach to minority rights in international law.

Kymlicka is right that there is a huge gap in the current 'generic rights' stream of international law between, on the one hand, the universal cultural rights of Art. 27 of the International Covenant on Civil and Political Rights and, on the other hand, the right of self-determination of peoples proclaimed by the UN Charter and both UN human rights conventions. Yet adding targeted self-government rights for specific kinds of minorities would not address the deeper cause of the problem, which is the irreconcilable tension between self-determination and territorial integrity. As long as self-determination remains there as the ultimate prize, many minority nationalists will regard rights to territorial autonomy as only a first step, while most governments will see them as one step too far. What we need instead are normative principles for accommodating rival claims that support equilibrium solutions (Laitin, 2007).

As I have suggested elsewhere, this would require abandoning selfdetermination as a general principle and promoting instead a general right to self-government that applies to existing states as well as to historic substate political communities, and even to transnational modes of citizenship that link migrants and diaspora communities with an external 'homeland' (Bauböck, 2006). A principle of unilateral self-determination is not universalizable, whereas a principle of self-government can be applied universally as long as all rights-holders are required to accommodate rival claims by accepting nested and overlapping political jurisdictions. I am perfectly aware that this proposal entails a quite radical departure from current international law since it challenges the current equation between sovereign states and self-governing political communities. But it seems to me a more coherent answer than liberal nationalism can provide to the question of how tensions between security and justice can be reduced through strengthening progressive principles in international law (see also Buchanan, 2004).

My second critique concerns the culturalist foundations of Kymlicka's approach. As he has explained in his earlier work, Kymlicka thinks that liberals ought to value membership in a cultural community not as an object of individual choice, but as a background that makes other choices in one's life meaningful. A background culture that enables individuals to be autonomous must generally be 'an intergenerational community, more or less institutionally complete, occupying a given territory or homeland, 
sharing a distinct language and history (Kymlicka, 1995: 14), in other words, a nation. This core element of Kymlicka's theory has been criticized both from sociological and normative perspectives. The latter critique points out that opportunities for individual autonomy may be greater where the background culture is itself multicultural and where individuals are seen to belong to several cultures simultaneously (Waldron 1996). The former critics have accused Kymlicka of reifying national cultures that are themselves constantly in flux and constructed by government institutions and ethnic entrepreneurs in order to gain popular support for their claims (Brubaker, 2004).

I cannot engage here with the substance of these charges, but I think they do touch a weak spot when it comes to promoting liberal multiculturalism in the international arena and to defending it against critics in domestic ones. Kymlicka's culturalist justification for minority rights is at odds with the normative foundations of modern human rights law and raises therefore suspicions among progressive international lawyers. The hard core of minority rights in international law is not grounded in values of either cultural diversity or cultural belonging, but in individual liberty and equality and assumptions about 'standard threats' to these values in modern states and societies. One good reason why international law does not, and should not, refer more explicitly to the value of cultural membership is that there is little hope to find consensus on what this value might be and what it entails for state duties of cultural protection.

Instead of taking the detour via the value of cultural membership, it seems to me much more promising to refer directly to three basic values of international human rights law. These are: liberty, equality and self-government. Article 27 ICCPR (International Covenant on Civil and Political Rights) rights of minorities 'to enjoy their own culture, to profess and practise their own religion, or to use their own language' can be easily defended on grounds of liberty of thought, speech and association. The core principle of non-discrimination in human rights law can support more farreaching duties of governments to provide protection to individuals and to ensure that cultural membership does not become a disadvantage in access to other basic public goods and resources. A more comprehensive notion of equality can also support exemptions from certain public laws for religious minorities or claims to symbolic recognition and material support for minorities, but these kinds of cultural rights are difficult to generalize across contexts and need to be negotiated in democratic settings.

For the rights that I have listed so far, invoking a cultural justification may not be the best strategy to defend them, but it makes little difference with regard to the outcome. The question becomes really important only in specifying the third value of self-government. If international law attributed a right to self-government to specific groups on the basis of their cultural characteristics then it would directly contribute to the reification of group 
identities and would provide incentives for nationalist entrepreneurs as well as for national governments to prove their claims through strategies of cultural homogenization.

The main deficit in the current normative framework of international law is that there is no coherent answer to the question of how to resolve conflicts over which territory belongs to which jurisdiction and which political community individuals ought to be citizens of. These boundary issues would become even more difficult to address once we mix them with claims to cultural protection, cultural homelands and cultural membership. The alternative answer of sticking simply to the value of equality is not helpful either, since it presupposes an answer to the question: equality among whom? The boundaries of political communities must be settled first before we can develop a full account of equality among those who are rightfully subjected to a particular jurisdiction.

What can be done by international law and international organizations in answering these boundary questions? My hunch is that we do need general principles for the settlement of territorial conflict and for allocating citizens to specific political communities at sub-state, state, and suprastate levels. However, in order to be sufficiently universal, these principles must remain fairly general. One cannot and should not specify in advance the cultural characteristics of groups that can claim self-government rights. Ultimately, devolving self-government powers to territorial sub-units is a matter of constitutional settlements within particular polities. Negotiating these rights in democratic deliberations is the only way for how they can be specified. In such negotiations, each side has to show that it has a democratic mandate for its claims. And working out arrangements of nested selfgovernment in such a setting will in turn strengthen commitment to democracy among all parties involved (Laitin, 2007: Ch. 5).

Where the preconditions for such negotiated settlements are absent or where negotiations fail and break down into violent conflict, the international community may have to mediate or intervene. But the modes of self-government that can keep together deeply diverse polities must ultimately be worked out by these societies themselves. Social scientists can compare solutions that have worked and specify the conditions under which they have worked and political theorists can elaborate the normative principles that ought to be accepted by all involved in such conflicts. But ultimately, it is for citizens and their representatives to work out how to distribute self-government power across political communities whose territories and membership overlap with each other.

Kymlicka's account of liberal multiculturalism in the international arena remains torn between the foundations of his normative theory and realistic insights into the limitations of international law. This tension cannot be fully resolved, but it could be alleviated by shedding some of the culturalist and nationalist baggage of the theory. 


\section{Notes}

1 Jonathan Glover has stated this nicely as a variation on Kant's categorical imperative: 'Always treat nations merely as means and never as ends in themselves' (Glover, 1997: 29).

\section{References}

Bauböck, Rainer (2006) 'Paradoxes of Self-determination and the Right to Selfgovernment', in Chris Eisgruber and Andras Sajo (eds) Global Justice and the Bulwarks of Localism: Human Rights in Context, pp. 101-28. Leiden, Netherlands: Martinus Nijhoff Publishers.

Brubaker, Rogers (2004) Ethnicity Without Groups. Cambridge, MA: Harvard University Press.

Buchanan, Allen (2004) Justice, Legitimacy, and Self-Determination. Moral Foundations for International Law. Oxford: Oxford University Press.

Cassese, Antonio (1995) Self-Determination of Peoples. A Legal Reappraisal. Cambridge: Cambridge University Press.

Glover, Jonathan (1997) Nations, Identity, and Conflict, in Robert McKim and Jeff McMahan (eds) The Morality of Nationalism, pp. 11-30. Oxford: Oxford University Press.

Kymlicka, Will (1995) Multicultural Citizenship. Oxford: Oxford University Press.

Kymlicka, Will (2001) Politics in the Vernacular. Nationalism, Multiculturalism and Citizenship. Oxford: Oxford University Press.

Laitin, David (2007) Nations, State, and Violence. Oxford: Oxford University Press. Miller, David (1995) On Nationality. Oxford: Oxford University Press.

Tamir, Yael (1993) Liberal Nationalism. Princeton, NJ: Princeton University Press. Waldron, Jeremy (1996) 'Multiculturalism and Melange', in Robert K. Fullinwider (ed.) Public Education in a Multicultural Society, pp. 90-118. Cambridge: Cambridge University Press.

RAINER BAUBÖCK is Professor of social and political theory at the European University Institute, Italy. Address: European University Institute,via dei Roccettini, 9, I-50014 San Domenico di Fiesole (FI), Italy. [email: rainer.baubock@eui.eu] 